\title{
Suppression of Cyclin-Dependent Kinase 5 Activation by Amyloid Precursor Protein: A Novel Excitoprotective Mechanism Involving Modulation of Tau Phosphorylation
}

\author{
Ping Han, ${ }^{1}$ Fei Dou, ${ }^{2}$ Feng Li, ${ }^{1}$ Xue Zhang, ${ }^{1}$ Yun-Wu Zhang, ${ }^{1}$ Hui Zheng, ${ }^{3}$ Stuart A. Lipton, ${ }^{1}$ Huaxi Xu, ${ }^{1}$ and \\ Francesca-Fang Liao ${ }^{1}$ \\ ${ }^{1}$ Center for Neuroscience and Aging, The Burnham Institute, La Jolla, California 92037, ${ }^{2}$ Department of Genetic and Development Biology, State Education \\ Ministry Laboratory of Developmental Genes and Human Disease, Southeast University Medical School, Nanjing, China 210009, and ${ }^{3}$ Huffington Center on \\ Aging, Baylor College of Medicine, Houston, Texas 77030
}

\begin{abstract}
Alzheimer's disease is cytopathologically characterized by loss of synapses and neurons, neuritic amyloid plaques consisting of $\beta$-amyloid $(\mathrm{A} \beta)$ peptides, and neurofibrillary tangles consisting of hyperphosphorylated tau protein in susceptible brain regions. $\mathrm{A} \beta$, which triggers a cascade of pathogenic events including tau phosphorylation and neuronal excitotoxicity, is proteolytically derived from $\beta$-amyloid precursor protein (APP); the pathological and physiological functions of APP, however, remain undefined. Here we demonstrate that the level of tau phosphorylation in cells and brains deficient in APP is significantly higher than that in wild-type controls, resulting from activation of cyclin-dependent kinase 5 (CDK5) but not glycogen synthase kinase 3 , the two major tau kinases. In addition, we show that overexpression of APP or its non-amyloidogenic homolog amyloid precursor-like protein 1 suppresses both basal and stress-induced CDK5 activation. The ectodomain of APP, $\operatorname{sAPP} \alpha$, is responsible for inhibiting CDK5 activation. Furthermore, neurons derived from APP-deficient mice exhibit reduced metabolism and survival rates and are more susceptible to excitotoxic glutamateinduced apoptosis. These neurons also manifest significant defects in neurite outgrowth compared with neurons from the wild-type littermates. The observed neuronal excitotoxicity/apoptosis is mediated through a mechanism involving CDK5 activation. Our study defines a novel neuroprotective function for APP in preventing tau hyperphosphorylation via suppressing overactivation of CDK5. We suggest that CDK5 activation, through a calcium/calpain/p25 pathway, plays a key role in neuronal excitotoxicity and represents an underlying mechanism for the physiological functions of APP.
\end{abstract}

Key words: $\beta$-amyloid precursor protein; CDK5; tau; phosphorylation; excitotoxicity; neurite outgrowth

\section{Introduction}

The amyloidogenic peptides $(\mathrm{A} \beta)$ deposited in neurotic plaques are the proteolytic cleavage products of the amyloid precursor protein (APP) (Greenfield et al., 2000). A $\beta$ has been documented to trigger a cascade of pathogenic events such as calcium influx involving excitoactivation of glutamate/NMDA receptors and dystrophy of neurites, culminating in neuronal apoptosis/death (Bossy-Wetzel et al., 2004). Multiple lines of evidence have also indicated a causal link of $\mathrm{A} \beta$ to neurofibrillary tangle (NFT) formation; $\mathrm{A} \beta$ has been shown to accelerate and augment NFT formation in tau transgenic mouse models (Gotz et al., 2001; Lewis

\footnotetext{
Received Sept. 9, 2005; revised 0ct. 25, 2005; accepted Nov. 2, 2005.

This work was supported by the National Institutes of Health Grants R01 NS046673 (H.X.), R01 AG024895 (H.X.), and P01 HD29587 (S.A.L), by the Alzheimer's Association (H.X.), by the American Health Assistance Foundation (H.X.) and by National Science Foundation of China Grant 30370311 (F.D.). We thank Helen Fang for expert technical assistance.

Correspondence should be addressed to either Dr. Francesca-Fang Liao or Dr. Huaxi Xu, Center for Neuroscience and Aging, The Burnham Institute, 10901 N. Torrey Pines Road, La Jolla, CA 92037. E-mail: fliao@burnham.org or xuh@burnham.org.

P. Han's present address: Neuroscience Research, Global Research and Department, Abbott Laboratories, Abbott Park, IL 60064 .

D0I:10.1523/JNEUROSCI.3831-05.2005

Copyright $\odot 2005$ Society for Neuroscience $\quad$ 0270-6474/05/2511542-11\$15.00/0
}

et al., 2001; Oddo et al., 2003, 2004). All of these findings strongly suggest a functional interaction between the $\mathrm{A} \beta$ and tau pathways. Because of the primacy of APP as the exclusive source of the $\mathrm{A} \beta$ and the initial genetic evidence causally linking aberrant $\mathrm{A} \beta$ production to familial Alzheimer's disease (AD), APP has remained at the center of $\mathrm{AD}$ research. The physiological functions of APP, however, are obscure; several neuritogenic roles, such as neuritic outgrowth/development, neuronal plasticity, and synaptive and neuroprotective functions, have been suggested (Mucke et al., 1996; Mattson, 1997; Neve et al., 2000; Koo, 2002).

Recently, cyclin-dependent kinase 5 (CDK5) has been implicated in AD pathogenesis (Cruz and Tsai, 2004). Despite its ubiquitous expression, CDK5 activity is almost exclusively restricted to postmitotic neurons because of the neuron-specific expression of its regulators p35/p39. CDK5 activity is critical to neurodevelopment because, in its absence, neuronal migration and axonal pathfinding are deranged (Ohshima et al., 1999). Deregulated (excessive and mislocalized) CDK5 activity appears to be detrimental to neuronal functions. During neuronal insult and subsequent disruption of calcium homeostasis, conversion of inactive p35 to active p25 is mediated via proteolytic cleavage by the calcium-regulated calpain. The activated CDK5 has been shown 
to promote phosphorylation of tau at $\mathrm{AD}$-specific epitopes, a prerequisite of paired helical filament (PHF) formation (Lee et al., 2000; Cruz et al., 2003; Noble et al., 2003). A role of CDK5 in neuronal death is also emerging (Town et al., 2002; Gamblin et al., 2003; Guo, 2003; Lee and Tsai, 2003), but evidence for a direct role is lacking.

In the current study, we investigate the physiological functions of APP in the context of kinase activation/phosphorylation of tau and neuronal survival/death in a mouse model deficient in APP. We demonstrate a novel function of APP in inhibiting tau phosphorylation (tau-P) by preventing CDK5 activation under basal and stress conditions. We further demonstrate that the activated CDK5 and elevated tau-P, resulting from increased intracellular calcium via glutamate/NMDA receptor pathways, are responsible for reduced survival rates and increased susceptibility to glutamate-induced cell death in APP-deficient neurons. Furthermore, cultured neurons from APP-deficient mice exhibit significant defects in neuritic outgrowth compared with their littermates, an effect primarily attributed to the lack of the neurotrophic factor, soluble $\operatorname{sAPP} \alpha$. These findings reveal a novel excitoprotective role of APP with significant pathophysiological relevance and delineate a mechanism/pathway for neuronal apoptosis and AD pathogenesis involving APP, CDK5 activation, and excitotoxicity.

\section{Materials and Methods}

Antibodies and chemicals. Tau H-150 (sc-5587), CDK5 C-8 (sc-173), and actin (sc-1615) antibodies were from Santa Cruz Biotechnology (Santa Cruz, CA). The phospho-specific tau antibodies AT-8, AT-100, AT-180, and AT-270 were purchased from Innogenetics (Ghent, Belgium); PHF-1 was a kind gift from Dr. Peter Davies (Albert Einstein College of Medicine, New York, NY). Rabbit polyclonal "369" that recognizes the C-terminal region of APP was raised by our laboratory (Xu et al., 1998). Mouse monoclonal antibodies 4G8 and 6E10 against $\mathrm{A} \beta$ were purchased from Signet Laboratories (Dedlam, MA); 22C11 against soluble APP was from Chemicon (Temecula, CA). Monoclonal antibodies against glycogen synthase kinase $3 \beta$ (GSK3 $\beta$ ) and $\gamma$-adaptin were from BD Transduction Laboratories (San Jose, CA), and rabbit anti-Ser-9 (GSK3 $\beta$ ) antibody was from Cell Signaling Technology (Beverly, MA). Histone H1 protein complex was from Roche Pharmaceuticals (Nutley, NJ). Alexa 488-conjugated anti-mouse IgG and Alexa-594-conjugated anti-rabbit IgG were from Invitrogen (Carlsbad, CA). Glutamate, NMDA, butyric acid (BA), LiCl, propidium iodide (PI), 4' $6^{\prime}$-diamidino-2-phenylindole/Hoechst, poly-D-lysine (molecular weight, $\sim 90 \mathrm{kDa}$; catalog \#P0899), 3-(4, 5-dimethylthiazol-2-yl)-2, 5-diphenyltetrazoliumbromide (MTT), and lactate dehydrogenase (LDH) kits were obtained from Sigma (St. Louis, MO). Terminal deoxynucleotidyl transferasemediated biotinylated UTP nick end labeling (TUNEL)/cell death detection kit and fluorescein were from Roche Diagnostics (Indianapolis, IN). The chemical inhibitors, including the three calpain inhibitors (calpain inhibitor I/N-acetyl-Leu-Leu-norleucinal, calpastatin/CS peptide, and PD150606), verapamil and roscovitine were purchased from Calbiochem/EMD Biosciences (San Diego, CA).

Cell cultures. Mouse neuroblastoma N2a cells and their derivative clones stably expressing human APP695, APPSwe, or APP C-terminal fragment (CTF) C99 were maintained in medium containing 50\% DMEM and 50\% Opti-MEM, supplemented with 5\% FBS and penicillin/ streptomycin. G418 (250 $\mu \mathrm{g} / \mathrm{ml}$; Invitrogen) was used in medium for N2a-derived stable cell lines.

Small interfering RNA-mediated APP gene silencing. A 21-mer RNA duplex corresponding to human APP695 open-reading frame 200-220 (5'- AAGGCAUCCUGCAGUAUUGCC-3') (Dharmacon Research, Lafayette, $\mathrm{CO}$ ) was transfected into N2a cells following the instructions of the manufacturer. Medium was changed on the second day, and APP protein expression was analyzed by Western blot 3 and $5 \mathrm{~d}$ after transfection.
Glutamate $/ \mathrm{H}_{2} \mathrm{O}_{2}$ and butyric acid treatments. To induce cytomegalovirus (CMV) promoter-driven APP transgene expression in N2a stable cell lines, $5 \mathrm{~mm}$ BA was added to the culture medium for 12 or $24 \mathrm{~h}$. N2a cells were also challenged with various neurotoxic agents, including excitotoxic amino acid glutamate (at 0.1 and $1 \mathrm{~mm}$ ) and $\mathrm{H}_{2} \mathrm{O}_{2}$ at $0.5 \mathrm{~mm}$ for $5 \mathrm{~h}$ before CDK5 assays.

CDK5 and GSK3 $\beta$ kinase assays. Cells and brain tissues were lysed in kinase extraction buffer ( $150 \mathrm{~mm} \mathrm{NaCl}, 20 \mathrm{~mm}$ Tris, pH7.4, 1 mм EDTA, 5 mм DTT, 0.5\% NP-40, $50 \mathrm{~mm} \mathrm{NaF}, 5 \mathrm{~mm} \mathrm{Na}_{3} \mathrm{VO}_{4}$, and a mixture of protease inhibitors) for $10 \mathrm{~min}$ on ice, and lysates were cleared by centrifugation. CDK5 protein was immunoprecipitated from the cell extracts containing $300 \mu \mathrm{g}$ of soluble proteins or the brain extracts containing $200 \mu \mathrm{g}$ of soluble proteins, using anti-CDK5 antibody-coupled agarose beads (Santa Cruz Biotechnology). The CDK5 kinase reaction was performed in $25 \mu \mathrm{l}$ of kinase reaction buffer containing $50 \mathrm{~mm}$ HEPES 7.4, $10 \mathrm{~mm} \mathrm{MgCl}{ }_{2}, 1 \mathrm{~mm}$ DTT, $0.5 \mathrm{~mm}$ ATP, $5 \mu \mathrm{g}$ of histone-H1, and $0.5 \mu \mathrm{Ci}$ of $\left[\gamma^{-32} \mathrm{P}\right] \mathrm{ATP}$ at $30^{\circ} \mathrm{C}$ for $15 \mathrm{~min}$. Reactions were terminated by transferring the tubes to ice for $5 \mathrm{~min}$, followed by addition of 5 $\mu \mathrm{l}$ of SDS sample loading buffer $(6 \times)$. The samples were boiled and electrophoresed using 12\% SDS-PAGE, followed by autoradiography. Results were quantified using a Molecular Dynamics (Sunnyvale, CA) PhosphoImager. For GSK $3 \beta$ kinase assays, cell lysates were similarly prepared, and the assay was performed in $50 \mu \mathrm{l}$ of kinase reaction buffer containing $50 \mathrm{~mm}$ HEPES 7.4, $10 \mathrm{~mm} \mathrm{MgCl}_{2}, 1 \mathrm{~mm}$ DTT, $0.25 \mathrm{mg} / \mathrm{ml}$ BSA, $0.2 \mathrm{~mm}$ ATP, and $0.2 \mathrm{~mm}$ cAMP response element-binding protein (CREB) peptide (New England Biolabs, Beverly, MA) plus $0.5 \mu \mathrm{Ci}$ of $\left[\gamma^{-}{ }^{32} \mathrm{P}\right]$ ATP at $30^{\circ} \mathrm{C}$ for $15 \mathrm{~min}$. Kinase reactions were quenched by transferring the tubes onto ice for $10 \mathrm{~min}$. Phosphorylation of CREB peptide substrate by GSK3 kinase was determined by dotting the reaction mixture solution onto P81 Whatman (Clifton, NJ) filter discs. After complete absorption of the reaction mixture, filter discs were washed three times in $75 \mathrm{~mm}$ phosphoric acid for $10 \mathrm{~min}$, completely dried at $80^{\circ} \mathrm{C}$, and counted in a scintillating counter. GSK3 $\beta$ kinase activity was confirmed by Western blot analysis of phospho-Ser 9 (1:500; Cell Signaling Technology), a negative regulatory site that inversely correlates with the kinase activity.

Immunoprecipitation and Western blot analysis. Assays were performed using standard procedures as described previously (Xu et al., 1998).

Immunohistochemistry and immunocytochemistry. Mouse brains were soaked in 30\% sucrose solution overnight before mounting with OKT cryostat medium (Fisher Scientific, Pittsburgh, PA) on dry ice and sliced into $15 \mu \mathrm{m}$ sections on a cryostat. Sections were fixed with $4 \%$ paraformaldehyde at room temperature for $15 \mathrm{~min}$ and permeabilized in $0.25 \%$ NP-40/PBS solution for $10 \mathrm{~min}$ on ice. After washes in PBS, specimens were blocked with PBS solution containing 3\% BSA, 3\% fetal calf serum, and $3 \%$ goat serum at room temperatures for $30 \mathrm{~min}$ in a humid chamber. Primary antibodies diluted in the blocking buffer were applied to the specimens and incubated for $1 \mathrm{~h}$ at room temperature. After extensive washes, Alexa 488-conjugated anti-mouse secondary antibody (1:200 dilution), combined with propidium iodide $(0.5 \mu \mathrm{g} / \mathrm{ml})$, were applied and incubated for $1 \mathrm{~h}$ at room temperature. Slides were mounted in Fluoromount medium, and immunofluorescent signals were observed under confocal microscopy (LSM510; Zeiss, Oberkochen, Germany). For immunocytochemistry of tau-P, cells were fixed and permeabilized, followed by addition of primary antibodies (against specific tau-P epitopes at 1:500 dilution) and the corresponding secondary antibodies. Fluorescent images were captured using an Olympus Optical (Tokyo, Japan) (1x71) microscope at $100 \times$ oil immersion objective.

Primary neuronal cultures from APP knock-out and wild-type mice. Sufficient numbers of mice with littermate controls were obtained by using the mating strategies as described previously (Zheng et al., 1995). In particular, heterozygotes of APP mice were crossbred to generate littermates containing one of the three genotypes $\left(\mathrm{APP}^{+/+}, \mathrm{APP}^{+/-}\right.$, and $\mathrm{APP}^{-1-}$ ), which were genotyped by $\mathrm{PCR}$ amplification of genomic DNA isolated from mouse tails using primers specific for mouse APP [P1, 5'-CTG CTG CAG GTG GCT CTG CA-3'; P2, 5' -CAG CTC TAT ACA AGC AAA CAA G-3']. Primary neuronal cultures from postnatal day 0 (P0) mice were prepared as described previously (Cai et al., 2003). In brief, hippocampal and cerebral cortical tissues were removed and di- 
gested with $0.125 \%$ trypsin solution for $30 \mathrm{~min}$. The resulting dissociated cells were plated in DMEM containing 5\% FBS for 2-3 h and switched to serum-free Neurobasal medium (Invitrogen), supplemented with B27 and $0.5 \mathrm{~mm}$ glutamine, and cultured for more than 2 weeks at $37^{\circ} \mathrm{C}$ with $5 \% \mathrm{CO}_{2}$. In some experiments, purified sAPP $\alpha$ ( $5 \mathrm{nM}$ ) or roscovitine (20 $\mu \mathrm{M}$ ) was added in neuronal cultures from day 1 and replenished every $3 \mathrm{~d}$ throughout the $2-3$ week period.

Assessment of cell survival and mitochondria activity. Isolated primary neurons were plated onto coverslips precoated with poly-D-lysine (100 $\mu \mathrm{g} / \mathrm{ml}$ ) at a density of 75,000 per well in 24-well plates. MTT and LDH assays were performed according to the procedures recommended by the manufacturers.

Excitotoxicity assays: glutamate/NMDA-induced neuronal cell death. Primary hippocampal neurons were isolated and purified from embryonic day 17 (E17) embryos of Sprague Dawley rats as described previously (Xu et al., 1998), resulting in $>95 \%$ neuronal purity as confirmed by staining with neuronal marker proteins neuronal-specific nuclear protein/microtubule-associated protein-2 (MAP-2) (Sigma). The cultures were maintained in serum-free Neurobasal medium for 2 weeks to allow development of glutamate receptors before being challenged with glutamate $(1 \mathrm{~mm}, 30 \mathrm{~min})$ or NMDA $(300 \mu \mathrm{M}, 15 \mathrm{~min})$ in $\mathrm{Mg}^{2+}$-free Eagle's balanced salt solution (EBSS) containing $1.8 \mathrm{mM} \mathrm{CaCl}_{2}$ and 500 $\mu \mathrm{M}$ glycine. After NMDA exposure, cells were gently washed with EBSS/ $1.8 \mathrm{mM} \mathrm{CalCl}_{2}$ and $1.2 \mathrm{mM} \mathrm{MgCl}_{2}$ and returned to the original culture medium for an additional $16-24 \mathrm{~h}$ at $37^{\circ} \mathrm{C}$ with $5 \% \mathrm{CO}_{2}$ before being assessed for cell death. Various inhibitors, including three calpain inhibitors, roscovitine, and $\mathrm{LiCl}$ were added $30 \mathrm{~min}$ before, during, and after the NMDA exposure.

After treatment with cell death-inducing or blocking agents, cell death was assessed at various time points for necrosis and apoptosis. Necrosis was assessed by staining with a membrane-impermeable DNA-binding dye PI $(0.5 \mu \mathrm{g} / \mathrm{ml}, 5 \mathrm{~min})$ on live cells. Cells were then fixed and permeabilized with $4 \%$ paraformaldehyde/PBS for $20 \mathrm{~min}$ at room temperature and $0.2 \%$ Triton X-100/PBS for $5 \mathrm{~min}$ on ice. Apoptotic neurons were identified by TUNEL colabeled with a neuron-specific marker (MAP-2), followed by counterstaining with membrane-permeable DAPI $(0.1 \mu \mathrm{g} /$ $\mathrm{ml}, 5 \mathrm{~min}$ ). In addition to TUNEL, apoptosis was assessed by condensed morphological changes of nuclei. In most experiments, cell survival was also assessed by trypan blue exclusion. A total of 400-500 neuronal cells were counted in 10 randomized fields.

Statistical analysis. Data are presented as mean \pm SEM. For statistical comparison, the Student's $t$ test was used. $p$ values smaller than 0.05 were considered to be statistically significant.

\section{Results}

\section{APP knock-out mice exhibit increased tau phosphorylation}

To study the possible role of APP in regulating phosphorylation of the microtubule binding protein tau, we first compared the profile of tau phosphorylation in the brains of APP knock-out (KO) and wild-type (WT) littermate mice using twodimensional PAGE analysis to separate phosphorylated tau species. In APP KO brains from 4-month-old animals, a marked increase in negatively charged tau species representing hyperphosphorylated forms accompanied a decrease in tau species representing lower degrees of phosphorylation (Fig. 1A). Similar patterns of increased hyperphosphorylated tau species were observed in the brains of APP KO mice at various ages $(2,6,9$, and 12 months of age; data not shown).

To further dissect the sites of tau phosphorylation, we used several phospho-tau antibodies to detect site-specific tau phosphorylation. In APP KO brains, tau phosphorylation at several sites known to be prominent in PHF were all increased, as evidenced by Western blot analysis using the phospho-specific antibodies PHF-1, AT-8, AT100, and AT-180, which recognize phosphorylation sites Ser-404, Ser-202/Thr205, Thr-212/Ser214, and Thr-231, respectively (Fig. $1 B$ ). In contrast, no significant increase in tau phosphorylation at Thr-175 or Thr-181 (po- tential mitogen-activated protein kinase sites; recognized by antibody AT270) was observed in APP KO samples (data not shown). Total tau protein from soluble extracts of mouse brain was unchanged between APP KO and WT samples, as shown with antibody $\mathrm{H}-150$, which recognizes a region common to all tau isoforms.

Elevated tau phosphorylation in APP KO mouse brain was further substantiated by immunohistochemistry using the same panel of phospho-specific antibodies. Consistent with the biochemical data, APP KO brains exhibited more intensive antiphospho-tau staining for each phosphorylation-specific epitope compared with WT control brains (Fig. 1C). In particular, AT100 antibody decorated thin fiber-like structures, which appeared to be distinct from cell nuclei and likely associated with the cytoskeleton in neuronal processes. In contrast, AT-180 epitopes mostly associated with cell nuclei and appeared to be enriched in the cell body. Additionally, many cells stained positive for AT-8 antibody (arrows). AT-270, as shown by biochemical evidence, was not changed in APP KO mouse brains. This differential distribution of various phospho-tau epitopes likely reflects different stages of tau filament formation as well as variable localization of the kinases that phosphorylate them.

Because the increased tau phosphorylation corresponded to the putative sites for CDK5 and GSK3 $\beta$ kinases (Buee et al., 2000; Iqbal et al., 2005), we examined the activity for these two major kinases. In vitro kinase assays for CDK5 and GSK3 $\beta$ were performed on mouse brain homogenates. Although the total protein levels of the kinases were similar (Fig. $1 B$ ), the brain CDK5 activity was significantly $(>60 \%)$ higher in APP KO mice at 4 months of age (Fig. 1D) compared with APP WT littermate control mice. However, little difference in GSK3 $\beta$ activity was observed between these mice (Fig. 1D). GSK3 $\beta$ activity was also assessed by Western blot analysis of phosphorylation at the Ser-9 site and found unchanged in APP KO mice (data not shown). These results also suggested that CDK5 is likely responsible for the elevated tau-P in APP KO brains.

\section{APP levels inversely correlate with CDK5 activity}

We next determined the relationship between APP dosage and CDK5 activity. First, we quantified the levels of APP expression and CDK5 activity in brain extracts isolated from mouse progenies of APP heterozygote parents; the littermates displayed one of three genotypes: $\mathrm{APP}^{+/+}$(WT), $\mathrm{APP}^{+/-}$(heterozygote), or $\mathrm{APP}^{-l-}(\mathrm{KO})$. We observed an inverse correlation between APP and CDK5 activity (Fig. $2 A$ ), which was further corroborated in mouse neuroblastoma N2a cells by downregulation of APP with small interfering RNA (siRNA). At a concentration of $5 \mathrm{~nm}$, transfection of APP siRNA duplex resulted in a $30 \%$ inhibition of APP expression $3 \mathrm{~d}$ after transfection and a $45 \%$ decrease $5 \mathrm{~d}$ after transfection compared with random siRNA transfection. CDK5 activity was increased by $\sim 20$ and $\sim 50 \%$ after 3 and $5 \mathrm{~d}$ of transfection with APP siRNA, respectively (Fig. $2 B$ ). APP siRNA specifically inhibited APP gene expression without affecting actin expression. Concentrations of APP siRNA above $10 \mathrm{nM}$ resulted in significant cytotoxicity and therefore were not tested further.

Having demonstrated a significant increase in CDK5 activity with reduced APP levels, we postulated that overexpression of APP may suppress CDK5 activity. To test this idea, we expressed high levels of APP in N2a cells stably transfected with the Swedish mutant form of human APP695 or WT. The level of APP was threefold greater in WT APP or mutant APP transfectants than in the nontransfected parental cells. Compared with the parental line, N2a cells overexpressing either WT APP695 or the Swedish 
A.

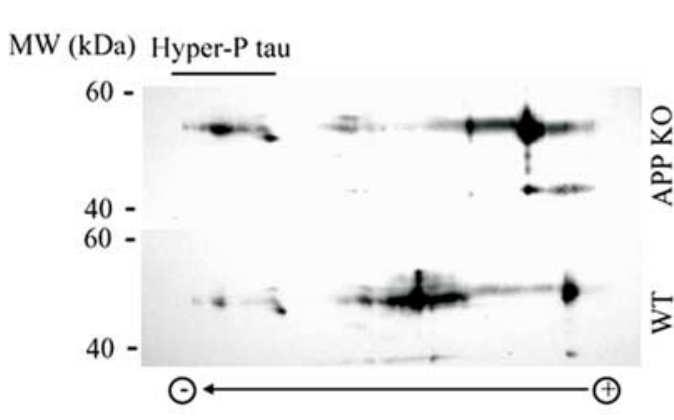

B.

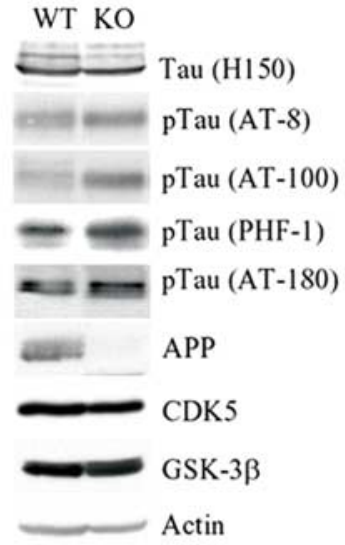

D.

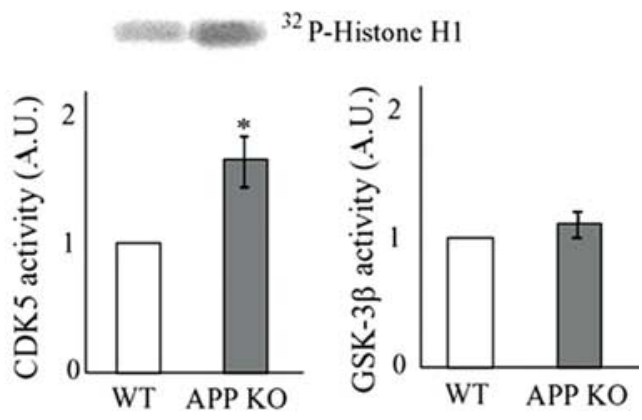

C.

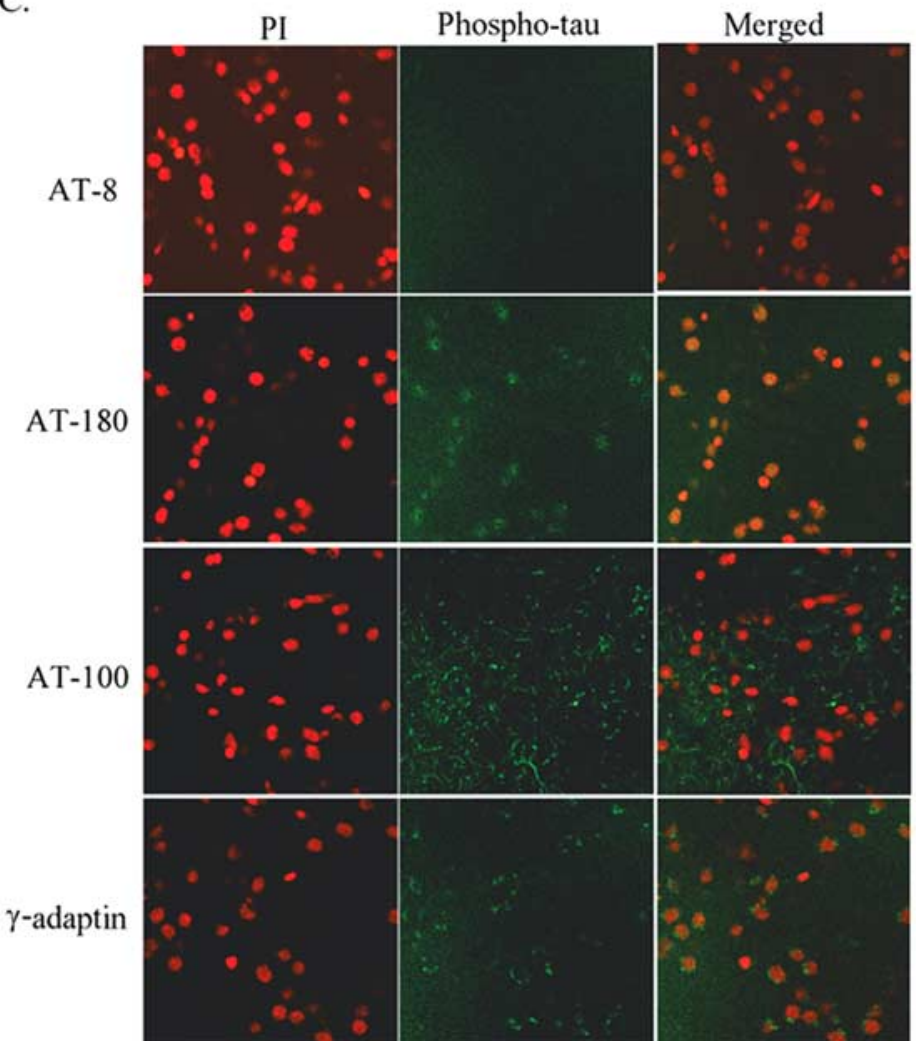

WT
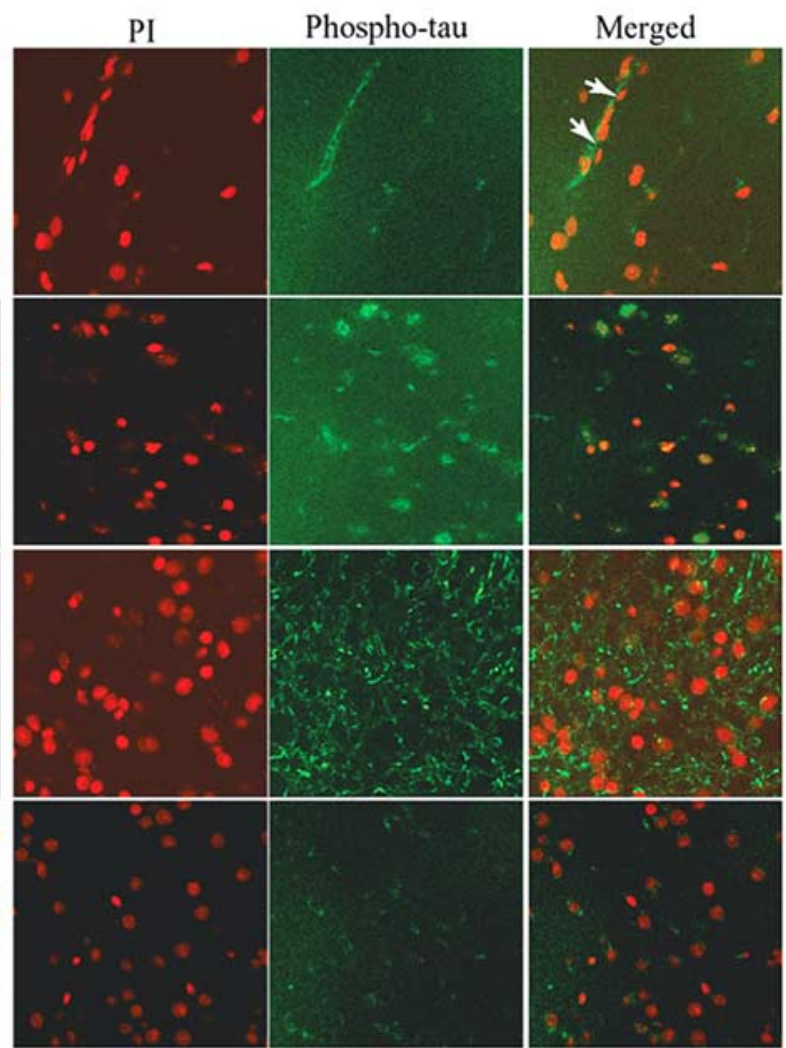

APP KO

Figure 1. APP deficiency results in increased brain tau phosphorylation and CDK5 activity. Brain homogenates were prepared from APP K0 and littermate control APP WT mice at 4 months of age. A, Two-dimensional PAGE analysis for determination of tau phosphorylation. One hundred micrograms of protein were used for the two-dimensional gel analysis. The first-dimension consisted of isoelectric focusing on a Protean IEF (Bio-Rad, Hercules, CA) (with a pH range of 3-10) cell, and the second-dimension consisted of SDS-PAGE separation using a precast criterion 4-15\% gradient gel. $\boldsymbol{B}$, Alteration of tau phosphorylation at various amino acid sites in APP KO brains. Brain homogenates were subjected to immunoprecipitation using H-150 antibody, which recognizes total tau protein, followed by Western blot analysis for total tau (using H-150 antibody) and for phosphorylated tau species using phospho-tau-specific antibodies AT-8, AT-100, PHF-1, and AT-180. Western blot assays for full-length APP (using antibody 369), CDK5, GSK3 $\beta$, and actin were performed. C, Confocal microscopic study of different phospho-tau isoforms in the cortical regions of APP K0 and APP WT mice. Frozen brain sections from wild-type mice (left) and APP K0 mice (right) were probed with phospho-tau-specific antibodies AT-8, AT-100, AT-180, and trans-Golgi network marker protein $\gamma$-adaptin, followed by fluorescein-coupled secondary antibody (green). Cell nuclei were stained with propidium iodide (red). D, Tau kinase activity in APP K0 and WT mouse brains. CDK5 activity was assayed by examining in vitro phosphorylation of histone-H1 protein as substrate in the presence of $\left[\gamma^{-}{ }^{32}\right.$ P]ATP, followed by SDS-PAGE and autoradiography. GSK-3 $\beta$ activity was measured by in vitro phosphorylation of CREB peptide with GSK3 $\beta$ immunoprecipitates, followed by scintillation counting using a $\beta$-counter. Data represent mean $\pm S D ; n=4$. ${ }^{*} p<0.005$ versus WT control.

variant possessed significantly $(\sim 50 \%)$ lower basal CDK5 activity, regardless of the higher levels of $\mathrm{A} \beta$ in the two transfectants (Fig. 2C). These data further support the inverse relationship between APP level and CDK5 activity.

Because the exogenous human APP constructs are under the control of CMV promoter whose expression can be induced by a low concentration of butyric acid, we pretreated N2a cells overexpressing the Swedish APP with butyric acid for 12 or $24 \mathrm{~h}$. CDK5 activity increased after the treatment, concomitantly with increased APP and A $\beta$ levels (Fig. $2 C$ ). It has been shown previously that $A \beta$ can stimulate CDK5 activity, which may mediate in part the neurotoxic effects of $A \beta$ (Cruz and Tsai, 2004; Esposito et 
A. WT $+/-$

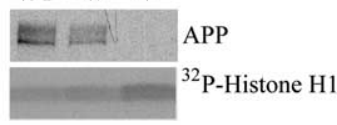

B. Cont. $\frac{\text { siRNA }}{5}$ 5 (d)
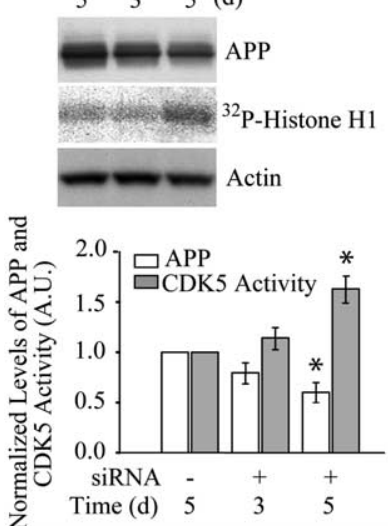

C.
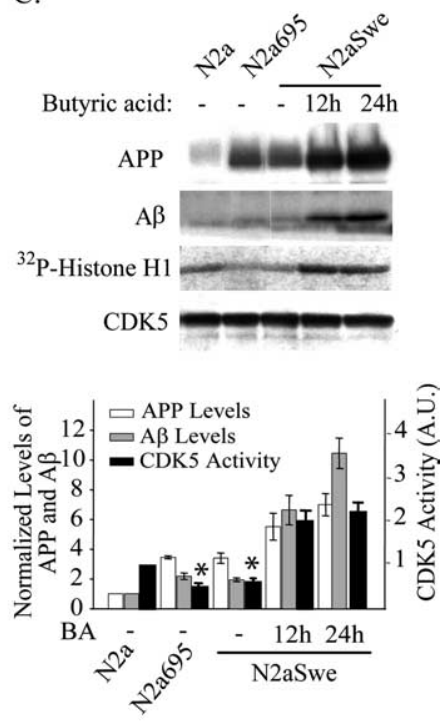

Figure 2. CDK5 activity inversely correlates with APP levels. $A$, CDK5 activity was measured in the brains of APP WT $(+/+)$, heterozygous $(+/-)$, and homozygous $(-/-)$ KO mice. The levels of APP were measured by Western blot analysis. $B$, Downregulation of APP expression by siRNA induced CDK5 activity. N2a cells were transfected with APP siRNA or nonspecific/random siRNA [control (Cont.)] for 3 or $5 \mathrm{~d}$. CDK5 activity was measured, and the levels of APP and actin were analyzed by Western blot. Actin was used for normalization of protein loading. Data represent mean $\pm S D ; n=3 ;{ }^{*} p<0.01$ compared with control siRNA. C, Distinct effects of APP and A $\beta$ on CDK5 activity. Parental N2a cells, N2a cells stably expressing wild-type human APP 695 , or the Swedish mutant form of APP 695 were incubated in the absence or presence of $5 \mathrm{~mm}$ butyric acid for 12 or $24 \mathrm{~h}$, as indicated, to induce APP expression. APP, CDK5 activity, and CDK5 protein were assayed as described above. $A \beta$ was determined by immunoprecipitation of cultured media with 4G8 antibody, followed by Western blotting using 6E10 antibody (Xu et al., 1998). Levels of APP, $A \beta$, and CDK5 activity were quantified and normalized to that of parental N2a cells [defined as 1 arbitrary unit (A.U.)]. Data represent mean $\pm S D ; n=3 ;{ }^{*} p<0.05$ compared with N2a parental cells.

al., 2004; Liu et al., 2004). However, CDK5 activity failed to increase further after $24 \mathrm{~h}$ of butyric acid treatment, whereas the level of $\mathrm{A} \beta$ (and APP) continued to rise. Together, our data indicate that CDK5 activity is inversely related to the level of APP expression, and APP may counteract A $\beta$-induced CDK5 activation. Furthermore, the potential neuroprotective effects of APP may be separated from the potential neurotoxic effects of $A \beta$.

\section{APP suppresses stress-mediated CDK5 activation}

Next, we studied the molecular mechanisms/pathways underlying the modulatory role of APP on CDK5 activation and found they could be readily dissected in cell-based models. Because the p35 to 25 conversion in primary neuronal cultures occurs in the presence of various neuronal insults, such as excitotoxic glutamate, hydrogen superoxide $\mathrm{H}_{2} \mathrm{O}_{2}$, or $\mathrm{A} \beta$ peptides (Cruz and Tsai, 2004), we speculated that CDK5 activation represents a common mechanism for neurons in response to these stress-inducing agents. We thus treated the $\mathrm{N} 2$ a cell lines that we had created with stress-inducing agents ( $1 \mathrm{~mm}$ glutamate or $0.5 \mathrm{mM} \mathrm{H}_{2} \mathrm{O}_{2}$ ) and found that CDK5 activity was stimulated by 48 or $29 \%$, respectively, when normalized to the total CDK5 level (Fig. 3). Consistent with the protective role of APP, elevated CDK5 activity was less apparent when higher levels of APP were present in N2a695 cells.

Additionally, we found that increased CDK5 activity was mediated by intracellular calcium and calpain, because the L-type calcium channel inhibitor verapamil $(100 \mathrm{~nm})$ or various calpain

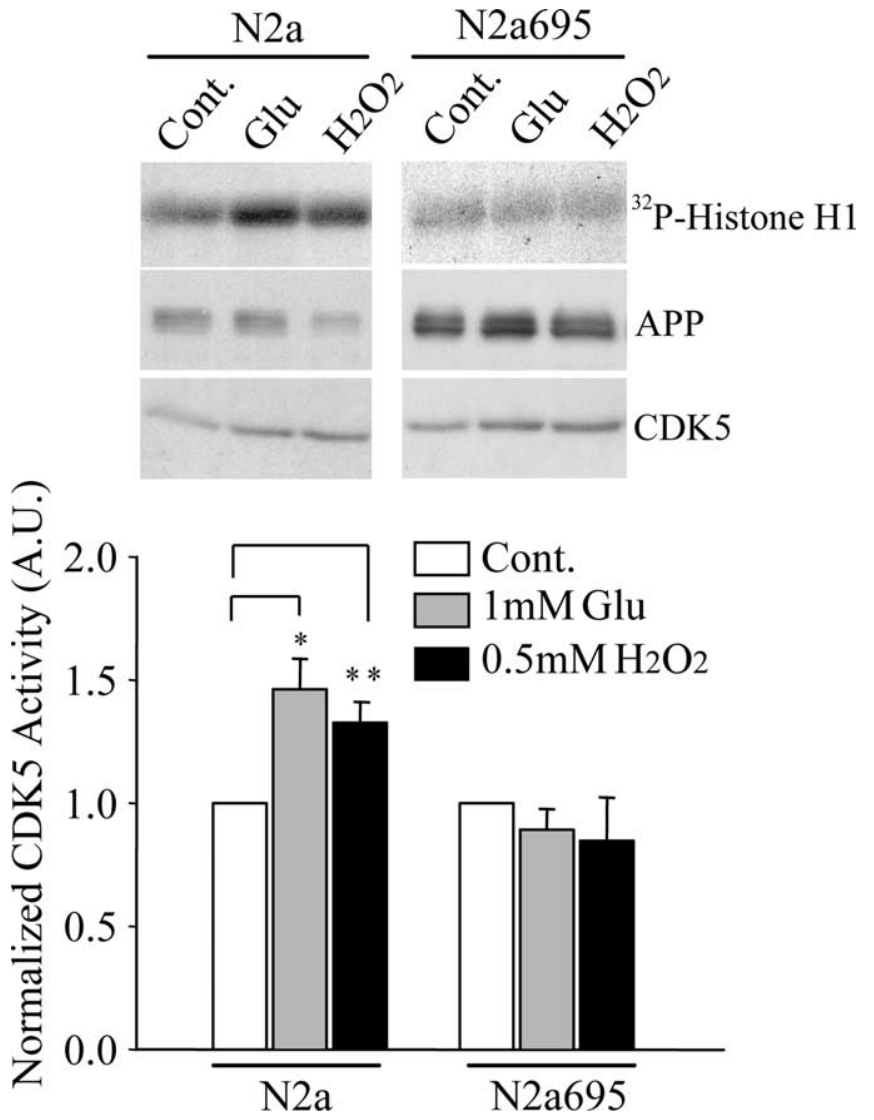

Figure 3. APP suppresses stress-mediated CDK5 activation. $A$, Parental N2a cells and N2a cells stably expressing WT APP 695 were treated with stress-inducing agents, 1 mm glutamate, or $0.5 \mathrm{~mm} \mathrm{H}_{2} \mathrm{O}_{2}$ for $5 \mathrm{~h}$ before being subjected to CDK5 kinase assays. $B$, CDK5 kinase activity was quantified and normalized to that of untreated controls. Data represent mean $\pm S D ; n=3$. ${ }^{*} p<0.02,{ }^{* *} p<0.05$ versus the control. Cont., Control, Glu, glutamate; A.U., arbitrary units.

inhibitors (50 nM capthesin/CS peptide, $10 \mu \mathrm{M}$ calpain inhibitor $\mathrm{I} / \mathrm{N}$-acetyl-Leu-Leu-norleucinal, or $10 \mu \mathrm{M}$ PD150606) completely abolished stress-induced increases in CDK5 activation, whereas $5 \mathrm{~mm} \mathrm{LiCl}$ (a dose that specifically inhibits GSK3 $\beta>$ GSK3 $\alpha$ ) showed no effect (data not shown).

\section{Soluble APP is sufficient to suppress stress-induced CDK5 activation}

We then examined whether the suppressive effect of APP on stress-induced CDK5 activity could be attributed to the soluble secreted form $\operatorname{sAPP} \alpha$. We first established in N2a cells that transiently expressed human APP695, as in stably transfected N2a695 cells, was able to prevent CDK5 activation during glutamate exposure. We then transiently expressed different APP fragments to assess the domain(s) required for the suppressive effect of APP. Overexpression of sAPP $\alpha$ or amyloid precursors-like protein 1 (APLP1), a non-amyloidogenic homolog of APP, dramatically suppressed glutamate-induced CDK5 activation. In contrast, APP C-terminus C99, a product of $\beta$-cleavage, failed to show any suppressive effect on CDK5 activation (Fig. 4A). Expression of each APP fragment was under the control of the same plasmid system as APP695, yielding similar levels of transgene products. The ability of APLP that lacks the amyloid sequence to suppress CDK5 activation further supported the protective effect of APP in contrast to A $\beta$. The ability of sAPP $\alpha$ to suppress CDK 5 activation was further confirmed using purified $\operatorname{sAPP} \alpha$. In a separate set of experiments, cell culture supernatants collected from confluent 

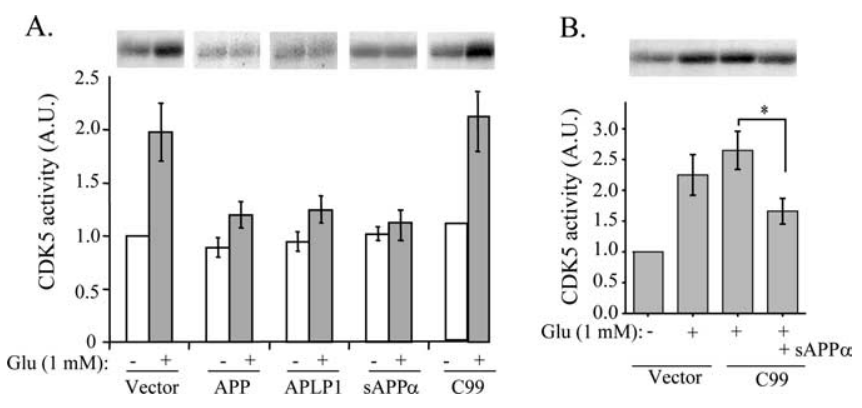

Figure 4. $\quad \boldsymbol{A}, \operatorname{SAPP} \alpha$ and APLP1, but not APP $\beta C T F$, suppress excitotoxicity-induced CDK5 activation. CDK5 activity was assayed in N2a cells stably overexpressing vector alone, APP695, APLP1, sAPP $\alpha$, or APP $\beta C T F$ (C99) with or without previous treatment with 1 mm glutamate. CDK5 activities were quantified and normalized to that of N2a cells expressing control vector without glutamate treatment (defined as 1 arbitrary unit). Error bars indicate $S D ; n=3$. $\boldsymbol{B}$, SAPP $\alpha$ is able to suppress glutamate-induced CDK5 activation in the presence of $A \beta$-bearing C99 fragment. A total of 10 nm purified SAPP $\alpha$ protein was added to N2a/APP $\beta$ CTF (C99) cells pretreated with $1 \mathrm{~mm}$ glutamate, and CDK5 activity was assayed and quantified. Data represent means \pm SD from three separate experiments; ${ }^{*} p<0.02$. A.U., Arbitrary units.

N2a cells overexpressing APP695 were used as a source of sAPP $\alpha$ after depleting A $\beta$ and APP CTFs using antibodies $4 \mathrm{G} 8$ and 369. The purified $\operatorname{sAPP} \alpha$ at $10 \mathrm{~nm}$ prevented glutamate-induced CDK 5 activation by $>50 \%$ in N2a cells stably expressing C99 (which can also produce A $\beta$ ) (Fig. $4 B$ ), whereas 5 nм sAPP $\alpha$ completely suppressed CDK5 activation in the parental N2a cells without $A \beta$ overproduction (data not shown).

\section{APP KO neurons are associated with reduced survival, increased apoptosis, and impaired neurite outgrowth}

The observation that APP KO mice exhibit mild motor dysfunction and brain gliosis (Zheng et al., 1995) is consistent with the proposed physiological roles of APP in neuron development. Studies of the physiological function of APP in cultured primary neurons have been inconsistent and controversial (Perez et al., 1997; Harper et al., 1998; White et al., 1998, 1999; Heber et al., 2000; Herms et al., 2004). Our data described above demonstrating differential responses to excitotoxic and oxidative insults between mouse brains or cells expressing various levels of APP, in the context of tau phosphorylation and CDK5 activation, suggest an excitoprotective role of APP. We therefore further examined the survival, apoptotic susceptibility, and neurite outgrowth in neurons lacking APP in response to excitotoxic insults. We cultured both hippocampal and cerebral cortical neurons from APP $\mathrm{KO}$ and littermate control animals within $24 \mathrm{~h}$ of birth (P0). We observed no defects in cell attachment in APP KO neurons, and similar neuronal cell densities were achieved after $2 \mathrm{~d}$ in culture for APP KO and WT neurons. However, the APP KO cells exhibited much lower survival rates, as assessed by MTT and LDH assays. The basal MTT/cell survival was significantly lower in APP KO cells examined $14 \mathrm{~d}$ after culture (Fig. 5A), and APP KO neurons were more susceptible to glutamate exposure compared with the WT controls, which was primarily restored by exogenously added $\operatorname{sAPP} \alpha$. The sensitivity of neuronal cells to glutamate/NMDA usually increases with the number of days in culture because of expression of the full-spectrum of NMDA-type receptors and channels on the cell surface (Bonfoco et al., 1995). To ensure maximum sensitivity to NMDA receptor-dependent responses, all excitoactivity-related experiments were conducted in primary neurons cultured for at least 2 weeks.

Significantly increased $\mathrm{LDH}$ release was found to be associated with APP KO neurons, accompanied by dramatically in- creased apoptosis: $\sim 35-40 \%$ of APP KO neurons died after 2 weeks in cultures, most likely via an apoptotic mechanism as evidenced by condensed nuclei (Fig. $5 B$, insets). Glutamate exposure $(1 \mathrm{~mm}$ for $24 \mathrm{~h}$ ) reduced the cell viability to $<20 \%$ in APP KO neurons compared with $\sim 50 \%$ in WT neurons. As determined by morphological examination, the surviving APP KO neurons also displayed defects in neurite outgrowth and branching; both the number and length of dendrites were reduced by twofold to threefold (Fig. 5C). Similar results were obtained with neurons isolated from E17 stage embryos. Similar to its effects on preventing CDK5 activation, soluble sAPP $\alpha$ rescued these defects to a large extent (Fig. 5C), confirming its neurotrophic and neuroprotective effects. In parallel, addition of the CDK5 inhibitor roscovitine $(20 \mu \mathrm{M})$ resulted in a slight but significant $(>20 \%)$ increase in the mitochondria activity/survival rate as well as neuritic outgrowth on APP KO neurons during glutamate treatment (data not shown), suggesting that CDK5 is directly involved in the reduced neuronal survival and neuritic outgrowth.

\section{Calpain/p25/CDK5 is a major determinant in excitotoxicity}

Our findings, along with others, indicate that CDK5 is one of the key mediators regulating both amyloidogenesis and formation of tau/NFTs (Otth et al., 2002; Town et al., 2002; Lee and Tsai, 2003). Therefore, we studied the role of CDK5 in neuronal cell death in the context of excitotoxicity. Although the detailed molecular mechanisms remain to be fully defined, increased calcium influx, mediated by overactivation of glutamate receptors, is known to be a major culprit triggering the excitotoxic cell death cascade. We hence used a commonly used experimental model of delayed neuronal death involving overactivation of glutamate receptors. Exposure of rat hippocampal or cerebral cortical neurons to the selective glutamate receptor agonist NMDA, dependent on time and concentration, induced both necrosis and apoptosis, the two major forms of neuronal death in both acute and chronic pathological conditions such as ischemic brain trauma after stroke and chronic brain injury in many neurodegenerative diseases, including AD (Lipton and Rosenberg, 1994; Ankarcrona et al., 1995; Nicotera et al., 1997; Yuan et al., 2003; Dickson, 2004; Prunell and Troy, 2004). Consistent with previous reports (Bonfoco et al., 1995), we found that exposure of cultured neurons with $300 \mu \mathrm{M}$ NMDA for $15 \mathrm{~min}$ in the presence of $500 \mu \mathrm{M}$ glycine induced early necrosis in only a small subset of cells $(\sim 5 \%)$. A delayed massive apoptosis $(50-75 \%)$ became evident in neurons that survived the initial necrotic insult after a period of 4-24 h (Fig. 6A).

We next addressed the question whether CDK5 activation via calpain-mediated p35 to p25 conversion is involved in neuronal excitoxicity. The following studies were conducted in the NMDA-induced cell death system. Activation of calciumactivated calpain I occurred rapidly after exposure to NMDA, which contributed to early necrosis because all three calpain inhibitors tested protected cells from necrosis when they were applied during but not after NMDA exposure (Fig. 6B). Similar protective effects were achieved by 5-20 $\mu \mathrm{M}$ roscovitine in a dosedependent manner; within this range of low concentrations, roscovitine is known to selectively inhibit CDK5 activity but not other CDKs. Both calpain inhibitors and CDK5 inhibitor not only protected cells from early necrosis but also prevented subsequent apoptosis at least during the first $24 \mathrm{~h}$ after NMDA treatment. This finding suggests that calpain and p25/CDK5 are the major determinants during excitotoxic neuronal death. Inhibition of GSK $3 \beta$ kinase activity by $5 \mathrm{~mm} \mathrm{LiCl} \mathrm{had} \mathrm{no} \mathrm{significant}$ effect on excitotoxic cell death under our conditions. 
A.

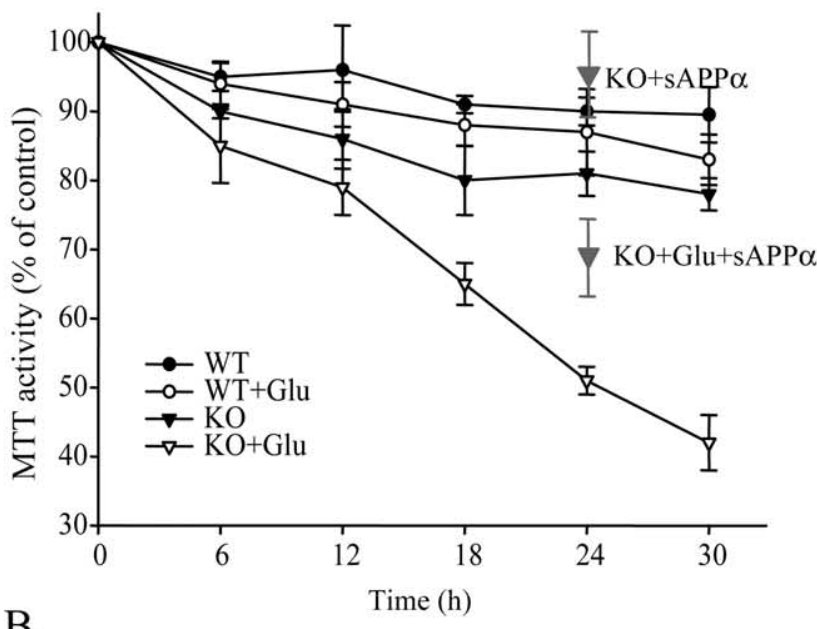

B.

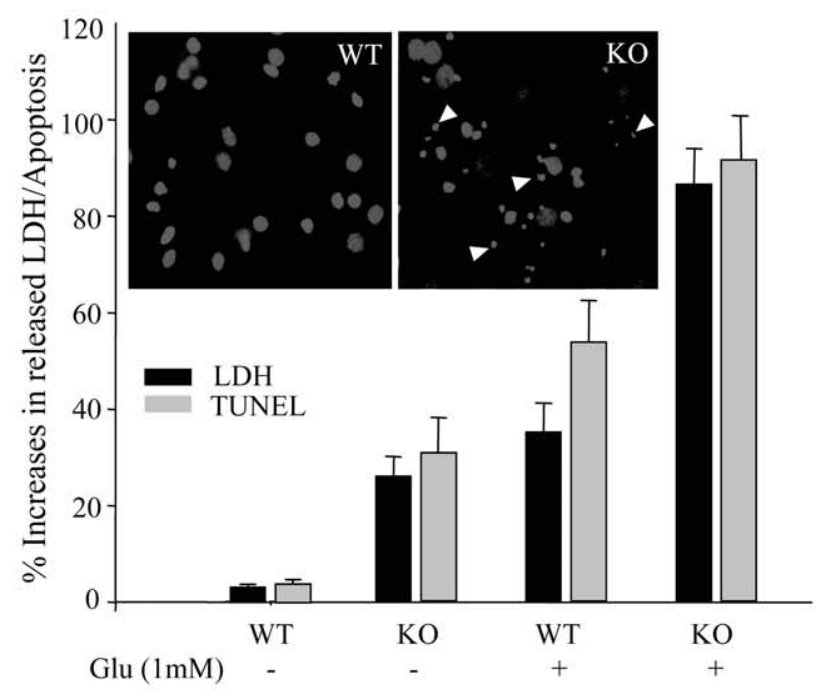

C.
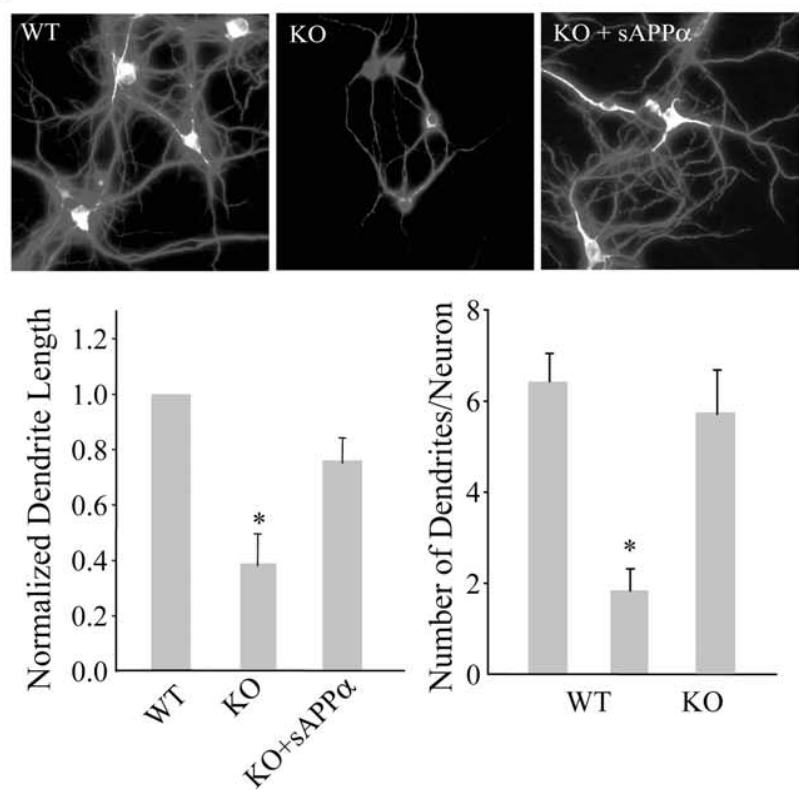

Figure 5. APP KO neurons exhibit reduced survival rates, increased susceptibility to apoptosis, and impaired neurite outgrowth. Primary cortical neurons were isolated from APP KO and littermate control APP WT mice at P0 and cultured for 2 weeks. A, Mitochondria function and
A.
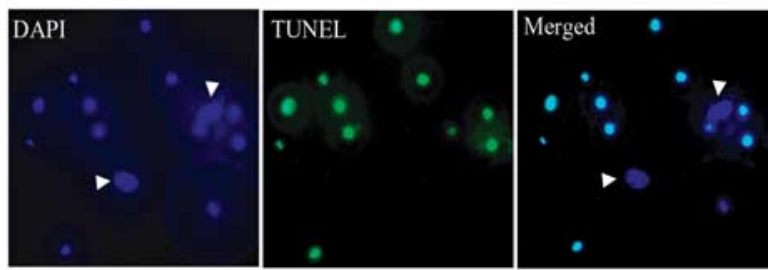

B.

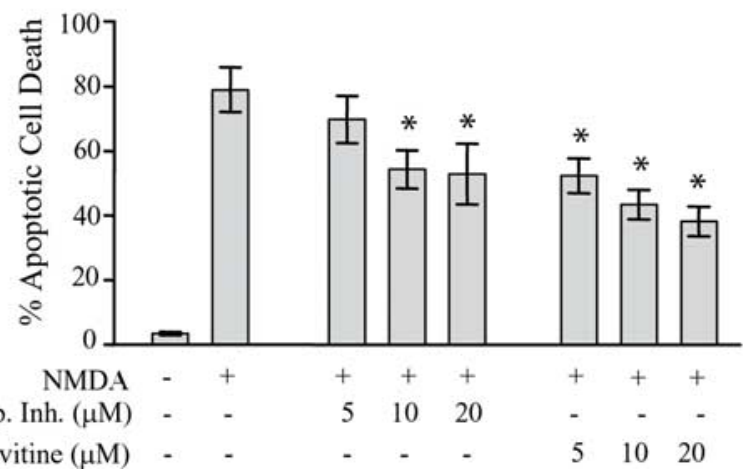

Figure 6. Calpain and CDK5 activation are involved in excitotoxicity of neurons. E17 rat primary hippocampal neuronal cultures were treated with $300 \mu \mathrm{m}$ NMDA for $15 \mathrm{~min}$ in the absence or presence of indicated concentrations of calpain inhibitors (Calp. Inh.) or CDK5 inhibitor (roscovitine). Images were captured $16 \mathrm{~h}$ after the treatment. $A$, Representative images of DAPI, TUNEL staining, and the merged picture of apoptotic neurons in response to NMDA exposure. The arrowhead indicates nonapoptotic nuclei. $\boldsymbol{B}$, Apoptotic neurons are quantified and represented by the percentage of MAP-2-positive pyknotic cells that colabeled with TUNEL and had condensed nuclei on DAPI staining. Data are mean $\pm \operatorname{SEM}(n=4) .{ }^{*} p<0.05$ versus NMDA alone.

CDK5 is responsible for glutamate-induced tau hyperphosphorylation in APP KO brains

Because glutamate is known to induce tau phosphorylation, which may subsequently contribute to neuronal excitotoxicity (Sindou et al., 1994), we thus investigated whether CDK5 is responsible for glutamate-induced tau phosphorylation in cultured rat hippocampal neurons. Indeed, we observed marked increases in tau-P on several distinct phospho-epitopes using immunocytochemistry after a brief ( $30 \mathrm{~min}, 1 \mathrm{~mm}$ ) glutamate exposure (Fig. 7, left two columns), with a similar pattern as seen in brain slices of APP KO mice (Fig. 1C). Under high-power magnification (100 $\times$ oil immersion objective), the details of the tau-P epitopes, including distribution and intensity, were examined and analyzed: the AT-100-positive signals decorated as thin fiber-like structures appeared to be associated with the cytoskeleton in neuronal processes. In contrast, both the AT-8- and the AT-180positive signals were mostly associated with cell nuclei and the

\footnotetext{
$\leftarrow$

survival of primary cortical neurons were assessed by MTT assay with and without $24 \mathrm{~h}$ glutamate (Glu) challenge. SAPP $\alpha$ ( $5 \mathrm{~nm}$ ) was added to APP KO neurons from day 1 throughout the entire culture period (red symbols). Data represent mean $\pm S D ; n=3 . \boldsymbol{B}$, Cell death in response to glutamate was assessed by released LDH, and apoptotic neurons were quantified by the percentage of MAP-2-positive pyknotic cells that colabeled with TUNEL and had condensed nuclei by DAPI staining $24 \mathrm{~h}$ after NMDA exposure. Two representative images are shown as insets: white arrowheads indicate apoptotic neurons. Numbers of neurons undergoing secondary necrosis (LDH) or apoptosis (TUNEL) were counted. Data represent mean \pm SEM $(n=4)$.C, APP WT and KO neurons were grown on myelin-coated slides for 2 weeks, followed by immunostaining for MAP-2. The length of neurites was quantified from 50 MAP-2-positive cells, and the number of processes projecting from each positive cell was also quantified. Error bars indicate mean $\pm S D ; p<0.01$ compared with WT controls, from three separate experiments.
} 

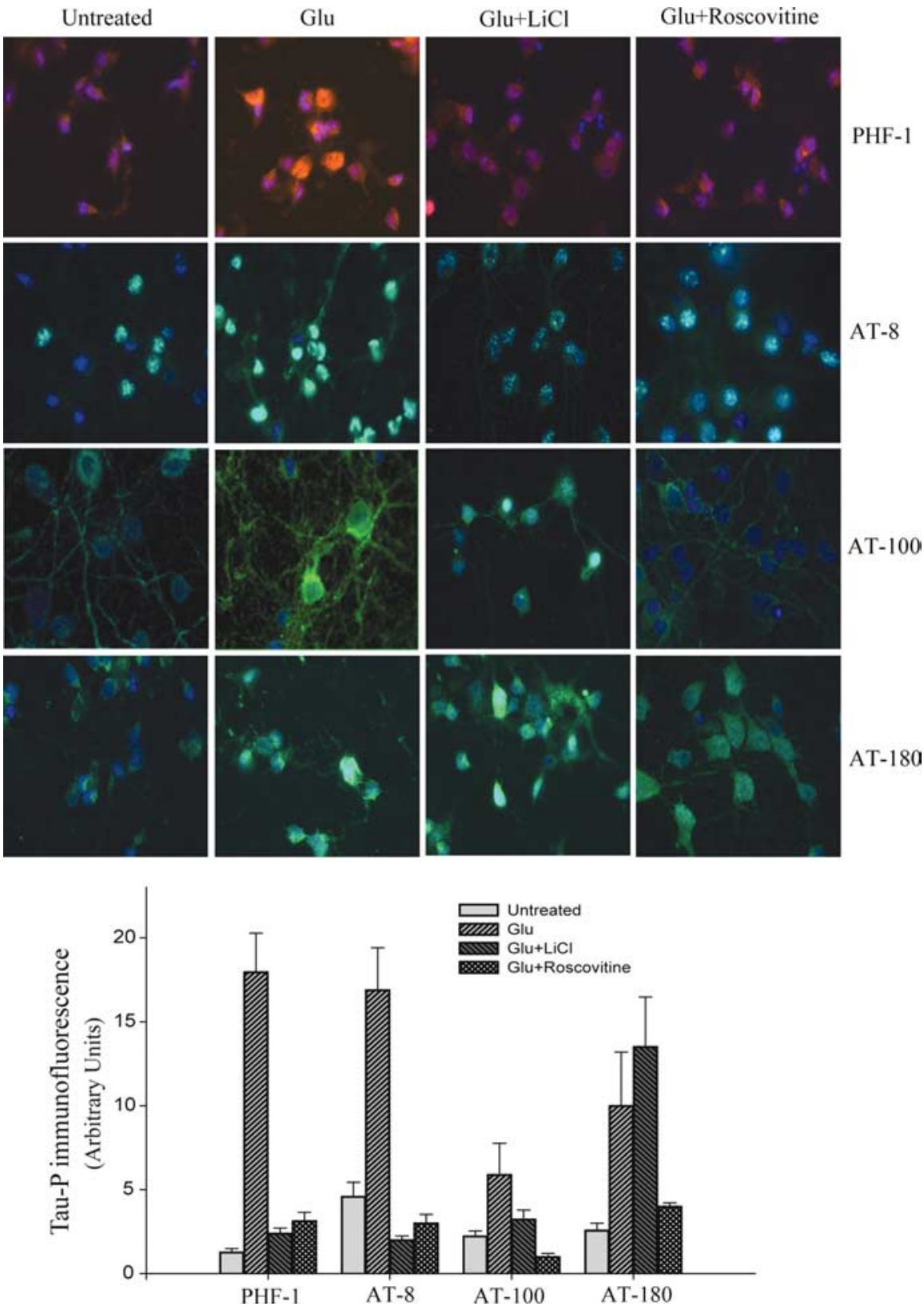

Figure 7. Excitotoxicity induces tau phosphorylation mediated by CDK5 activation. E17 rat hippocampal neurons were pretreated with $1 \mathrm{~mm}$ glutamate (Glu) with or without $5 \mathrm{~mm} \mathrm{LiCl}$ or roscovitine for $30 \mathrm{~min}$. Phospho-epitopes on tau proteins were examined by fluorescence microscopy using PHF1, AT-8, AT-100, or AT-180 antibodies. Representative micrographs of three separate experiments were presented ( $100 \times$ oil immersion objective). Immunofluorescence intensity of each tau-P epitope was quantified from four random fields ( 50 cells) and presented as fold increase over the negative control of secondary antibody alone.

cell body. AT-270 immunocytochemistry did not change during glutamate exposure (data not shown). Both roscovitine and $\mathrm{LiCl}$ prevented the glutamate-induced tau-P to various extents (Fig. 7, two right columns), and they appeared to equally block the PHF-1 and AT- 8 epitopes. A more dramatic effect was observed at the AT-100 epitope during CDK5 inhibition, which completely eliminated this epitope from the cell body and the processes to a level even lower than the basal. Interestingly, GSK3 $\beta$ inhibition only prevented distribution of this epitope from neuronal processes. This differentiated effect likely reflects different stages of tau filament formation and disparate localization of these two kinases. Notably, CDK5 inhibition resulted in a selective effect on the AT-180 epitope, whereas $\mathrm{LiCl}$ did not cause any reduction at this epitope. These findings demonstrate that CDK5 activity plays a major role in increased tau phosphorylation during excitotoxicity. The similarity in tau phosphorylation patterns between APP deficiency and glutamate stimulation also suggests that CDK5 is likely responsible for the elevated tau-P in APP KO mice.

\section{Discussion}

Since its cloning in the 1980s, APP has been the subject of unparalleled scrutiny. Besides being the substract of the $\beta$ - and $\gamma$-secretases that generate amyloidogenic $\mathrm{A} \beta$, the physiological functions of this highly abundant type-1 transmembrane protein remain elusive. Previous in vitro studies have suggested that APP may play a role in transmembrane signal transduction, calcium metabolism, and neurite outgrowth, but those studies require corroboration with in vivo evidence. Initial studies of APP KO mice did not reveal an obvious disease phenotype; however, more recent examination has revealed mild abnormalities such as impaired locomotor activity (Zheng et al., 1995), defective corpus collosum formation, longterm potentiation, and behavior (Muller et al., 1994; Dawson et al., 1999). Additionally, defects in synaptic density in the cortex (Magara et al., 1999; Seabrook et al., 1999) and hypersensitivity to seizures (Steinbach et al., 1998), especially at older ages, have been observed. In the current study, we report a novel observation that deficiency in APP results in greater levels of tau phosphorylation and CDK5 kinase activity. Elevated CDK5 activity, both basal activity and activation in response to excitotoxicity through calcium/calpainmediated pathways, not only causes hyperphosphorylation of tau but also contributes to increased susceptibility to neuronal death. This is the first demonstration, to our knowledge, of a direct role of CDK5 in excitotoxicity and thus adds to a growing body of evidence supporting a causative role of CDK5 in neuronal cell death.

We chose APP KO mice in our study because we believe that this system holds great advantages over previous in vitro and in vivo experimental systems overexpressing APP from which neuritogenic/neuroprotective functions of APP were deduced. These studies yielded conflicting results (Masliah et al., 1997; Zhang et al., 1997), partially because of the intrinsic differences among various models in terms of expression of specific forms of APP and the doses of transgenes. Moreover, the obfuscating neurotoxic effects of $\mathrm{A} \beta$ often overrode the protective effects of APP. This may be reflected in patients with Down's syndrome in which holoAPP is overexpressed: senile plaque densities are frequently higher in Down's syndrome patients than in $\mathrm{AD}$ patients; however, the developmental patterns of neurofibril- 
lary tangle formation are comparable (Hof et al., 1995). The analogy of overexpressed APP transgenic models to Down's syndrome is therefore not compelling for $\mathrm{AD}$, because there is no evidence for increased levels of APP in any forms of familial or sporadic AD. In fact, our data not only unambiguously demonstrate an inverse relationship between APP and stress-induced CDK5 activation but also corroborate a counterregulatory role of $\mathrm{A} \beta$ to the function of APP. Thus, both insufficient APP and excessive APP are detrimental to neurons. The ability of APLP to suppress CDK5 activity ensures a functional redundancy between APP and its homologs and may serve as a backup system for cells to provide neuroprotective functions under pathological conditions when aberrant APP processing and $\mathrm{A} \beta$ generation take place. The effect of APLP1, which lacks the A $\beta$ sequence, also strongly supports the notion that the observed effects of APP on tau phosphorylation, CDK5 activation, and neuronal survival are distinct from the detrimental effects of $\mathrm{A} \beta$.

We speculate that the phenotype of impaired neuronal function described above for APP KO mice could be attributed to the lack of neuroprotective sAPP $\alpha$ or to the reduced exonal transport functions caused by the formation of tau-P (Koo et al., 1990; Kamal et al., 2001; Stokin et al., 2005). Indeed, we found severely impaired neuronal maturation in APP KO mice under certain culture conditions. We used neuronal cultures derived from littermate control animals and assessed glutamate responses from neurons cultured for 2-3 weeks to allow expression of a fullspectrum of glutamate receptors on the cell surface. Our results demonstrate that the defect in APP KO neurons in culture is partially attributable to a lack of $\operatorname{sAPP} \alpha$, consistent with previous reports (Perez et al., 1997). In addition, given the fact that CDK5 is a major tau kinase, our results demonstrating the function of sAPP $\alpha$ in suppressing CDK5 activation under both normal and stress conditions suggest that $\operatorname{sAPP} \alpha$ is likely responsible for downregulating tau phosphorylation.

Our data that $\operatorname{sAPP} \alpha$ can restore stress-induced CDK5 activation suggests that the membrane-anchored form of APP is not required to inhibit CDK5 activation. The ability of exogenously added $\operatorname{sAPP} \alpha$, but not the cytoplasmic fragment (C99), to rescue MTT activity of APP KO neurons reconciles the neurotrophic/ survival roles documented previously (Mattson, 1997). It is presently unclear how sAPP $\alpha$ exerts these actions; both the upstream (membrane receptors) and the downstream signaling pathways underlying this protective effect are essentially undefined. Rohn et al. (2000) reported that monoclonal antibody 22C11, specific to N-terminal APP, mimics ligand (antagonist) binding and induces oxidative stress, neurite degeneration, and cell death. This finding suggests that interaction between the antibody and APP may mimic receptor cross-linking and thus disrupt signal transduction mechanisms mediated by APP. The notion that both APP and the membrane binding sites for $\operatorname{APP} \alpha$ primarily reside in lipid raft microdomains (Tikkanen et al., 2002; Ehehalt et al., 2003) suggests the possibility that $\operatorname{sAPP} \alpha$ interacts with APP through either homophilic interaction or indirectly with as yet unidentified functional ligands and thus acts in trans to transduce signals. Moreover, a synergistic mechanism has also been suggested to involve upregulation of common survival pathways (e.g., phosphatidylinositol 3-kinase/Akt) (Cheng et al., 2002) and anti-apoptotic factors (Bcl-2 and X-linked inhibitor of apoptosis protein) (our unpublished data).

How do the putative sAPP $\alpha$ receptor and second messengers impinge on CDK5? CDK5 has been suggested to play roles in both neuronal death and neuritic outgrowth, depending on its association with specific activators p35 or p25 (Cruz and Tsai, 2004).
CDK5 is known to phosphorylate APP at Thr-668 and may affect the proteolytic cleavage of APP, yielding either soluble sAPP $\beta$ and A $\beta$ or sAPP $\alpha$ (Oishi et al., 1997; Liu et al., 2003). The soluble sAPP fragments and the corresponding CTFs may interact with putative receptors and transduce signals to regulate neuronal activities. Additionally, a CDK5-dependent signaling cascade has been implicated in calcium-mediated cell death (Weishaupt et al., 2003). A broad spectrum of intracellular apoptosis-related substrates have been reported for CDK5 including (1) p53, which activates Bax and initiates the apoptotic cascade involving cytochrome $c$ apoptosis proteases-activating factor-1/caspase-9, (2) NMDA receptors that increase calcium influx/calpain activation/ p35-p25 conversion to prolonged activated CDK5, and (3) the nuclear transcription factor myocyte enhancer factor-2, which inhibits action of this prosurvival factor. Therefore, deregulation of CDK5 activity exacerbates neuronal death not only by enhancing cell death pathways but also by impairing prosurvival signaling (Cheung and Ip, 2004). Furthermore, CDK5 was also recently found to affect calcium transfer from the endoplasmic reticulum to mitochondria during $\mathrm{C} 2$-ceramide-induced neuronal cell death (Darios et al., 2005). Mutation of the CDK5 phosphorylation site Thr-231 (AT-180 epitope) prevented ceramide-induced release of tau from microtubules, organelle clustering, increased mitochondrial calcium levels, and neuronal death, indicating that the neurotoxic calcium transfer is regulated by CDK5dependent tau phosphorylation. The involvement of tau binding to microtubules in organelle trafficking has also been demonstrated in several non-neuronal systems (Rizzuto et al., 1998; Wang et al., 2000; Stamer et al., 2002). We found in our excitotoxic cell death model that CDK5 selectively phosphorylates Thr231, the AT-180 epitope (Fig. 7), and activates neuronal cell death pathways upstream of mitochondrial dysfunction (our unpublished data), suggesting a similar mechanism between nonneuronal cells (Weishaupt et al., 2003) and neurons during the excitoresponse. Blocking CDK5 activity may thus promote functional rescue from chronic neuronal injuries.

Whether CDK5 activation occurs during conversion of $\mathrm{p} 35$ to p25 or with increased p25 in brains of AD patients is still controversial (Tandon et al., 2003). However, evidence from transgenic mouse models overexpressing p 25 has been convincing and consistently demonstrates a causative effect of p25/CDK5 in hyperphosphorylation of tau (Ahlijanian et al., 2000; Cruz et al., 2003; Noble et al., 2003). Additionally, aggregation of phosphorylated tau has been implicated recently in neuronal cell death (Delobel et al., 2004). Although our study demonstrates a parallel increase in CDK5-mediated tau phosphorylation and excitotoxicity in the absence of APP, it also suggests a possible link between tau phosphorylation and neuronal loss. Our observation, which would predict more severe tau pathology in the absence of APP, seemingly contradicts the lack of severe NTF and neuronal loss in APP $\mathrm{KO}$ mice. This discrepancy may be attributable to intrinsic differences between mouse and human isoforms of tau, with mouse tau being less prone to NFT/apoptosis. This proposition may also explain why all of the available mouse models overexpressing human FTDP (frontotemporal dementia and parkinsonism) mutant tau in the presence of the endogenous mouse tau isoforms have failed to recapitulate $\mathrm{AD}$-like neuronal loss.

CDK5 inhibitors have been shown to reduce tau phosphorylation and neuronal death (Zheng et al., 2005). Here, we demonstrate a pivotal role of calpain and CDK5 in neuronal cell death, which appears to involve phosphorylation of tau at certain epitopes under excitotoxic conditions. Thus, it is reasonable to predict that inhibition of CDK5 holds promise in ameliorating 
tangle progression and subsequent neuronal death. Strategies may involve use of small-molecule inhibitors of CDK5 and enhancement of APP homeostasis.

\section{References}

Ahlijanian MK, Barrezueta NX, Williams RD, Jakowski A, Kowsz KP, McCarthy S, Coskran T, Carlo A, Seymour PA, Burkhardt JE, Nelson RB, McNeish JD (2000) Hyperphosphorylated tau and neurofilament and cytoskeletal disruptions in mice overexpressing human p25, an activator of cdk5. Proc Natl Acad Sci USA 97:2910-2915.

Ankarcrona M, Dypbukt JM, Bonfoco E, Zhivotovsky B, Orrenius S, Lipton SA, Nicotera P (1995) Glutamate-induced neuronal death: a succession of necrosis or apoptosis depending on mitochondrial function. Neuron 15:961-973.

Bonfoco E, Krainc D, Ankarcrona M, Nicotera P, Lipton SA (1995) Apoptosis and necrosis: two distinct events induced, respectively, by mild and intense insults with $\mathrm{N}$-methyl-D-aspartate or nitric oxide/superoxide in cortical cell cultures. Proc Natl Acad Sci USA 92:7162-7166.

Bossy-Wetzel E, Schwarzenbacher R, Lipton SA (2004) Molecular pathways to neurodegeneration. Nat Med [Suppl] 10:S2-S9.

Buee L, Bussiere T, Buee-Scherrer V, Delacoutte A, Hof PR (2000) Tau protein isoforms, phosphorylation and role in neurodegenerative disorders. Brain Res Brain Res Rev 33:95-130.

Cai D, Leem JY, Greenfield JP, Wang P, Kim BS, Wang R, Lopes KO, Kim SH, Zheng H, Greengard P, Sisodia SS, Thinakaran G, Xu H (2003) Presenilin-1 regulates intracellular trafficking and cell surface delivery of beta-amyloid precursor protein. J Biol Chem 278:3446-3454.

Cheng G, Yu Z, Zhou D, Mattson MP (2002) Phosphatidylinositol-3kinase-Akt kinase and p42/p44 mitogen-activated protein kinases mediate neurotrophic and excitoprotective actions of a secreted form of amyloid precursor protein. Exp Neurol 175:407-414.

Cheung ZH, Ip NY (2004) Cdk5: mediator of neuronal death and survival. Neurosci Lett 361:47-51.

Cruz JC, Tsai L (2004) Cdk5 deregulation in the pathogenesis of Alzheimer's disease. Trends Mol Med 10:452-458.

Cruz JC, Tseng H, Goldman JA, Shih H, Tsai L (2003) Aberrant Cdk5 activation by 25 triggers pathological events leading to neurodegeneration and neurofibrillary tangles. Neuron 40:471-483.

Darios F, Muriel M, Khondiker E, Brice A, Ruberg M (2005) Neurotoxic calcium transfer from endoplasmic reticulum to mitochondria is regulated by cyclin-dependent kinase 5-dependent phosphorylation of tau. J Neurosci 25:4159-4168.

Dawson GR, Seabrook GR, Zheng H, Smith DW, Graham S, O'Dowd G, Bowery BJ, Boyce S, Trumbauer ME, Chen HY, Van der Ploeg LH, Sirinathsinghji DJ (1999) Age-related cognitive deficits, impaired longterm potentiation and reduction in synaptic marker density in mice lacking the beta-amyloid precursor protein. Neuroscience 90:1-13.

Delobel P, Mailliot C, Hamdane M, Sambo AV, Begard S, Violleau A, Delacourte A, Buee L (2004) Stable-tau overexpression in human neuroblastoma cells: an open door for explaining neuronal death in tauopathies. Ann NY Acad Sci 1010:623-634.

Dickson DW (2004) Apoptotic mechanisms in Alzheimer neurofibrillary degeneration: cause or effect? J Clin Invest 114:23-27.

Ehehalt R, Keller P, Haass C, Thiele C, Simons K (2003) Amyloidogenic processing of the Alzheimer beta-amyloid precursor protein depends on lipid rafts. J Cell Biol 160:113-123.

Esposito L, Gan L, Yu GQ, Essrich C, Mucke L (2004) Intracellularly generated amyloid-beta peptide counteracts the antiapoptotic function of its precursor protein and primes proapoptotic pathways for activation by other insults in neuroblastoma cells. J Neurochem 91:1260-1274.

Gamblin CT, Chen F, Zambrano A, Abraha A, Lagalwar S, Guillozet AL, Lu M, Fu Y, Garcia-Sierra F, LaPointe N, Miller R, Berry RW, Binder LI, Cryns VL (2003) Caspase cleavage of tau: linking amyloid and neurofibrillary tangles in Alzheimer's disease. Proc Natl Acad Sci USA 100:10032-10037.

Gotz J, Chen F, van Dorpe J, Nitsch RM (2001) Formation of neurofibrillary tangles in P301L tau transgenic mice induced by Abeta 42 fibrils. Science 293:1491-1494.

Greenfield JP, Gross RS, Gouras GK, Xu H (2000) Cellular and molecular basis of beta-amyloid precursor protein metabolism. Front Biosci 5:D72-D83.
Guo Q (2003) Cyclin-dependent kinase 5-a neuronal killer? Sci Aging Knowledge Environ 50:pe36.

Harper SJ, Bilslaud JG, Shearman MS, Zheng H, Van der Ploeg L, Sirinathsinghhi DJ (1998) Mouse cortical neurons lacking APP show normal neurite outgrowth and survival responses in vitro. NeuroReport 9:3053-3058.

Heber S, Herms J, Gajic V, Hainfellner J, Aguzzi A, Rulicke T, von Kretzschmar H, von Koch C, Sisodia S, Tremml P, Lipp HP, Wolfer DP, Muller U (2000) Mice with combined gene knock-outs reveal essential and partially redundant functions of amyloid precursor protein family members. J Neurosci 20:7951-7963.

Herms J, Anliker B, Heber S, Ring S, Fuhrmann M, Kretzschmar H, Sisodia S, Muller U (2004) Cortical dysplasia resembling human type 2 lissencephaly in mice lacking all three APP family members. EMBO J 23:4106-4115.

Hof PR, Bouras C, Perl DP, Sparks DL, Mehta N, Morrison JH (1995) Agerelated distribution of neuropathologic changes in the cerebral cortex of patients with Down's syndrome. Quantitative regional analysis and comparison with Alzheimer's disease. Arch Neurol 52:379-391.

Iqbal K, Alonso Adel C, Chen S, Chohan MO, El-Akkad E, Gong CX, Khatoon S, Li B, Liu F, Rahman A, Tanimukai H, Grundke-Iqbal I (2005) Tau pathology in Alzheimer disease and other tauopathies. Biochim Biophys Acta 1739:198-210.

Kamal A, Almenar-Queralt A, LeBlanc JF, Rfberts EA, Goldstein LS (2001) Kinesin-mediated axonal transport of a membrane compartment containing beta-secretase and presenilin-1 requires APP. Nature 14:643-648.

Koo EH (2002) The $\beta$-amyloid precursor protein (APP) and Alzheimer's disease: does the tail wag the dog? Traffic 3:763-770.

Koo EH, Sisodia SS, Archer DR, Martin LJ, Weidemann A, Beyreuther K, Fischer P, Masters CL, Price DL (1990) Precursor of amyloid protein in Alzheimer disease undergoes fast anterograde exonal transport. Proc Natl Acad Sci USA 87:1561-1565.

Lee MS, Tsai LH (2003) Cdk5: one of the links between senile plaques and neurofibrillary tangles? J Alzheimers Dis 2:127-137.

Lee MS, Kwon YT, Li M, Peng J, Friedlander RM, Tsai LH (2000) Neurotoxicity induced cleavage of p35 to p25 by calpain. Nature 405:360-364.

Lewis J, Dickson DW, Lin WL, Chisholm L, Corral A, Jones G, Yen SH, Sahara N, Skipper L, Yager D, Eckman C, Hardy J, Hutton M, McGowan E (2001) Enhanced neurofibrillary degeneration in transgenic mice expressing mutant tau and APP. Science 293:1487-1491.

Lipton SA, Rosenberg PA (1994) Mechanisms of disease: excitatory amino acids as a final common pathway for neurological disorders. N Engl J Med 330:613-622.

Liu F, Su Y, Li B, Zhou Y, Ryder J, Gonzalez-DeWhitt P, May PC, Ni B (2003) Regulation of amyloid precursor protein (APP) phosphorylation and processing by p35/Cdk5 and p25/Cdk5. FEBS Lett 547:193-196.

Liu T, Perry G, Chan HW, Verdile G, Martins RN, Smith MA, Atwood CS (2004) Amyloid-beta-induced toxicity of primary neurons is dependent upon differentiation-associated increases in tau and cyclin-dependent kinase 5 expression. J Neurochem 88:554-563.

Magara F, Muller U, Li ZW, Lipp HP, Weissmann C, Stagljar M, Wolfer DP (1999) Genetic background changes the pattern of forebrain commissure defects in transgenic mice underexpressing the beta-amyloid-precursor protein. Proc Natl Acad Sci USA 96:4656-4661.

Masliah E, Westland CE, Rockenstein EM, Abraham CR, Mallory M, Veinberg I, Sheldon E, Mucke L (1997) Amyloid precursor proteins protect neurons of transgenic mice against acute and chronic excitotoxic injuries in vivo. Neuroscience 78:135-146.

Mattson MP (1997) Cellular actions of beta-amyloid precursor protein and its soluble and fibrillogenic derivatives. Physiol Rev 77:1081-1132.

Mucke L, Abraham CR, Masliah E (1996) Neurotrophic and neuroprotective effects of hAPP in transgenic mice. Ann NY Acad Sci 777:82-88.

Muller U, Cristina N, Li ZW, Wolfer DP, Lipp HP, Rulicke T, Brandner S, Aguzzi A, Weissmann C (1994) Behavioral and anatomical deficits in mice homozygous for a modified beta-amyloid precursor protein gene. Cell 79:755-765.

Neve R, McPhie DL, Chen Y (2000) Alzheimer's disease: a dysfunction of the amyloid precursor protein. Brain Res 886:54-66.

Nicotera P, Ankarcrona M, Bonfoco E, Orrenius S, Lipton SA (1997) Neuronal necrosis and apoptosis: two distinct events induced by exposure to glutamate or oxidative stress. Adv Neurol 72:95-101.

Noble W, Olm V, Takata K, Casey E, Mary O, Meyerson J, Gaynor K, LaFran- 
cois J, Wang L, Kondo T, Davies P, Burns M, Veeranna, Nixon R, Dickson D, Matsuola Y, Ahlijanian M, Lau LF, Duff K (2003) Cdk5 is a key factor in tau aggregation and tangle formation in vivo. Neuron 38:555-565.

Oddo S, Caccamo A, Shepherd JD, Murphy MP, Golde TE, Kayed R, Metherate R, Mattson MP, Akbari Y, LaFerla FM (2003) Triple-transgenic model of Alzheimer's disease with plaques and tangles: intracellular Abeta and synaptic dysfunction. Neuron 39:409-421.

Oddo S, Billings L, Kesslak JP, Cribbs DH, LaFerla FM (2004) Abeta immunotherapy leads to clearance of early, but not late, hyperphosphorylated tau aggregates via the proteasome. Neuron 43:321-332.

Ohshima T, Gilmore EC, Longenecker G, Jacobowitz DM, Brady RO, Herrup K, Kulkami AB (1999) Migration defects of CDk5 (-/-) neurons in the developing cerebellum is cell autonomous. J Neurosci 19:6017-6026.

Oishi M, Nairn AC, Czernik AJ, Lim GS, Isohara T, Gandy SE, Greengard P, Suzuki T (1997) The cytoplasmic domain of Alzheimer's amyloid precursor protein is phosphorylated at Thr654, Ser655, and Thr668 in adult rat brain and cultured cells. Mol Med 3:111-123.

Otth C, Concha II, Arendt T, Stieler J, Schliebs R, Gonzalez-Billault C, Maccioni RB (2002) AbetaPP induces cdk5-dependent tau hyperphosphorylation in transgenic mice Tg2576. J Alzheimers Dis 4:417-430.

Perez RG, Zheng H, Lex HT, Ploeg V, Koo EH (1997) The $\beta$-amyloid precursor protein of Alzheimer's disease enhances neuron viability and modulates neuronal polarity. J Neurosci 17:9407-9414.

Prunell GF, Troy CM (2004) Balancing neuronal death. J Neurosci Res 78:1-6.

Rizzuto R, Pinton P, Carrington W, Fay FS, Fogarty KE, Lifshitz LM, Tuft RA, Pozzan T (1998) Close contacts with the endoplasmic reticulum as determinants of mitochondrial $\mathrm{Ca}^{2+}$ responses. Science 280:1763-1766.

Rohn TT, Ivins KJ, Bahr BA, Cotman CW, Cribbs DH (2000) A monoclonal antibody to amyloid precursor protein induces neuronal apoptosis. J Neurochem 74:2331-2342.

Seabrook GR, Smith DW, Bowery BJ, Easter A, Reynolds T, Fitzjohn SM, Morton RA, Zheng H, Dawson GR, Sirinathsinghji DJ, Davies CH, Collingridge Gl, Hill RG (1999) Mechanisms contributing to the deficits in hippocampual synaptic plasticity in mice lacking amyloid precursor protein. Neuropharmacology 38:349-359.

Sindou P, Lesort M, Couratier P, Yardin C, Esclaire F, Hugon J (1994) Glutamate increases tau phosphorylation in primary neuronal cultures from fetal rat cerebral cortex. Brain Res 646:124-128.

Stamer K, Vogel R, Thies E, Mandelkow E, Mandelkow EM (2002) Tau blocks traffic of organelles, neurofilaments, and APP vesicles in neurons and enhances oxidative stress. J Cell Biol 156:1051-1063.

Steinbach JP, Muller U, Leist M, LiZW, Nicotera P, Aguzzi A (1998) Hypersensitivity to seizures in beta-amyloid precursor protein deficient mice. Cell Death Differ 5:858-866.

Stokin GB, Lillo C, Falzone TL, Brusch RG, Rockenstein E, Mount SL, Raman R, Davies P, Masliah E, Williams DS, Goldstein LS (2005) Axonopathy and transport deficits early in the pathogenesis of Alzheimer's disease. Science 307:1282-1288.

Tandon A, Yu H, Wang L, Rogaeva E, Sato C, Chishti MA, Kawarai T, Hasegawa H, Chen F, Davies P, Fraser PE, Westaway D, St. George-Hyslop PH (2003) Brain levels of CDK5 activator p25 are not increased in Alzheimer's or other neurodegenerative diseases with neurofibrillary tangles. J Neurochem 86:572-581.

Tikkanen R, Icking A, Beicht P, Waneck GL, Volker H (2002) The receptorbound N-terminal ectodomain of the amyloid precursor protein is associated with membrane rafts. J Biol Chem 383:1855-1864.

Town T, Zolton J, Shaffner R, Schnell B, Crescentini R, Wu Y, Zeng J, DelleDonne A, Obregon D, Tan J, Mullan M (2002) p35/Cdk5 pathway mediates soluble amyloid- $\beta$ peptide-induced tau phosphorylation in vitro. J Neurosci Res 69:362-372.

Wang HJ, Guay G, Pogan L, Sauve R, Nabi IR (2000) Calcium regulates the association between mitochondria and a smooth subdomain of the endoplasmic reticulum. J Cell Biol 150:1489-1498.

Weishaupt JH, Kussmaul L, Grotsch P, Heckel A, Rohde G, Romig H, Bahr M, Gillardon F (2003) Inhibition of CDK5 is protective in necrotic and apoptotic paradigms of neuronal cell death and prevents mitochondrial dysfunction. Mol Cell Neurosci 24:489-502.

White AR, Zheng H, Galatis D, Maher F, Hesse L, Multhaup G, Beyreuther K, Masters Cl, Cappai R (1998) Survival of cultured neurons from amyloid precursor protein knock-out mice against Alzheimer's amyloid $\beta$ toxicity and oxidative stress. J Neurosci 18:6207-6217.

White AR, Multhaup G, Maher F, Bellingham S, Camakaris J, Zheng H, Bush AI, Beyreuther K, Masters Cl, Cappai R (1999) The Alzheimer's disease amyloid precursor protein modulates copper-induced toxicity and oxidative stress in primary neuronal cultures. J Neurosci 19:9170-9179.

Xu H, Gouras GK, Greenfield JP, Vincent B, Naslund J, Mazzarelli L, Fried G, Jovanovic JN, Seeger M, Relkin NR, Liao F, Checler F, Buxbaum JD, Chait BT, Thinakaran G, Sisodia SS, Wang R, Greengard P, Gandy S (1998) Estrogen reduces neuronal generation of Alzheimer beta-amyloid peptides. Nat Med 4:447-451.

Yuan J, Lipinski M, Degterev A (2003) Diversity in the mechanisms of neuronal cell death. Neuron 40:401-413.

Zhang F, Eckman C, Younkin S, Hsiso KK, Iadecola C (1997) Increased susceptibility to ischemic brain damage in transgenic mice overexpressing the amyloid precursor protein. J Neurosci 17:7655-7661.

Zheng H, Jiang M, Trumbauer ME, Sirinathsinghji DJ, Hopkins R, Smith DW, Heavens RP, Dawson GR, Boyce S, Conner MW, Stevens KA, Slunt HH, Sisodia SS, Chen HY, Van de Ploeg LH (1995) $\beta$-amyloid precursor protein-deficient mice show reactive gliosis and decreased locomoter activity. Cell 81:525-531.

Zheng Y, Kesavapany S, Gravell M, Hamilton RS, Schubert M, Amin N, Albers W, Grant P, Pant HC (2005) A Cdk5 inhibitory peptide reduces tau hyperphosphorylationand apoptosis in neurons. EMBO J 24:209-220. 